\title{
IZGUBLJENO VRIJEME U OTKRIVANJU I POČETKU LIJEČENJA TUBERKULOZE: ŠTO TREBA NAPRAVITI?
}

\author{
Anamarija JURČEV-SAVIČEVIĆ1,3, Sanja POPOVIĆ-GRLE², Rosanda MULIĆ ${ }^{3}$, Mladen \\ SMOLJANOVIĆ1,3 i Kornelija MIŠE ${ }^{3,4}$ \\ Nastavni zavod za javno zdravstvo Splitsko-dalmatinske županije, Split ${ }^{1}$, Klinika za plućne bolesti Jordanovac, \\ Zagreb², Medicinski fakultet Sveučilišta u Splitu ${ }^{3}$, Klinika za plućne bolesti Kliničkog bolničkog centra Split ${ }^{4}$, Split, \\ Hrvatska
}

Primljeno u srpnju 2011.

CrossCheck u lipnju 2012.

Prihvaćeno u lipnju 2012.

\begin{abstract}
Ovim istraživanjem željelo se odrediti veličinu i analizirati čimbenike koji utječu na kašnjenje u otkrivanju i započinjanju liječenja tuberkuloze. Oboljeli od plućne tuberkuloze detaljno su intervjuirani o rizičnom načinu života, različitim demografskim, socioekonomskim i zdravstvenim obilježjima te je izračunano vrijeme od početka simptoma do početka liječenja.

Medijan i 75. percentil navedenog vremena iznosili su 68 i 120 dana. Unutar mjesec dana od početka simptoma liječiti se počelo $16,7 \%$ bolesnika, u drugome mjesecu 23,8 \%, 23,3 \% u trećem mjesecu, 12,9\% u četvrtome mjesecu, dok je 23,3 \% ispitanika liječenje započelo više od četiri mjeseca nakon početka simptoma. Uporaba droga bila je povezana s vremenom dužim od medijana, što se smatralo dugim kašnjenjem $(p=0,021)$ u otkrivanju i liječenju tuberkuloze. Najniži stupanj obrazovanja $(p=0,021)$, minimalan $(\mathrm{p}=0,039)$ te minimalni do prosječni mjesečni obiteljski prihod $(\mathrm{p}=0,020)$, pušenje $(\mathrm{p}=0,050)$ i komorbiditet $(\mathrm{p}=0,048)$ pokazali su se značajnima kad je promatran 75 . percentil izmjerenog vremena, što se smatralo ekstremnim kašnjenjem. U multiplome modelu uporaba droga ostala je značajno povezana $\mathrm{s}$ dugim kašnjenjem, a najniži stupanj obrazovanja $(p=0,033)$, sadašnje $(p=0,017)$ i bivše $(p=0,045)$ pušačke navike s ekstremnim kašnjenjem.

U uvjetima smanjivanja incidencije tuberkuloze kašnjenje u otkrivanju i liječenju tuberkuloze može se smanjiti zdravstvenim prosvjećivanjem opće populacije ne samo o tuberkulozi nego i općenito o zdravlju te stavovima i navikama glede prevencije i ranog liječenja. Istodobno se mora povećati i znanje o tuberkulozi te dijagnostičke sposobnosti zdravstvenih radnika.
\end{abstract}

KLJUČNE RIJEČI: komorbiditet, obrazovanje, pijenje alkohola, prevencija, pušenje, zdravstvena skrb, zloporaba droga

Premda je tuberkuloza bolest stara koliko i čovječanstvo, svijet je još daleko od njezina iskorjenjivanja. Štoviše, broj oboljelih od tuberkuloze u svijetu raste, uz popratne probleme poput infekcije virusom humane imunodeficijencije (HIV) te multirezistentnih i prošireno rezistentnih oblika bolesti. Svjetska zdravstvena organizacija (SZO) izvijestila je da je u 2010. godini 8,8 milijuna ljudi oboljelo, a 1,4 milijuna umrlo od tuberkuloze, dok je trećina svjetske populacije ( 2 milijarde ljudi) inficirana bacilom tuberkuloze (1). 
Strategija Stop TB koju je osmislila i promovira Svjetska zdravstvena organizacija (SZO) poziva na intenzivne aktivnosti usmjerene borbi protiv tuberkuloze s različitih polazišnih točaka. Šesta komponenta strategije posebno je usmjerena omogućivanju i podupiranju različitih istraživanja. Dizajniranje i provođenje istraživanja bitnih na nacionalnoj razini može pomoći u prepoznavanju problema, pronalaženju rješenja i provođenju prikladnih mjera. Osnovni princip nadzora nad tuberkulozom jest smanjivanje prijenosa infekcije ranim otkrivanjem i ranim liječenjem zaraznih tuberkuloznih bolesnika (2).

Najvažniji izvor infekcije u populaciji jest neotkriveni bolesnik koji ima zarazni oblik tuberkuloze. Procijenjeno je da takav bolesnik može inficirati do 15 osoba na godinu i više od 20 osoba tijekom prirodnog razvoja bolesti do smrti (3). Zakasnjelo otkrivanje i liječenje oboljelih dovodi do težih oblika bolesti i većeg mortaliteta na razini pojedinca. Osim toga, ono je odgovorno za duže vrijeme zaraznosti na razini populacije (4).

Međutim nema globalno dogovorene dužine razdoblja između pojave simptoma bolesti i početka liječenja koja se smatra prihvatljivom. Prijelomna točka dužine kašnjenja u istraživanjima koja su se fokusirala na ovaj problem obično je definirana na dva načina: konsenzusom skupine stručnjaka o tome što smatraju prihvatljivim kašnjenjem (manje od 30, 60 ili xy dana) ili se rabio medijan dobivenih podataka (5). Većina takvih istraživanja provedena je u zemljama visoke ili niske incidencije tuberkuloze $(6$, 7). S druge strane, radovi s tom problematikom nisu brojni u zemljama srednje incidencije gdje je potrebno intenzivno djelovati kako bi se tuberkuloza spustila na ljestvici vodećih nacionalnih javnozdravstvenih prioriteta.

Stopa incidencije tuberkuloze u Hrvatskoj iznosi 19 na 100000 stanovnika te je u polaganom, ali kontinuiranom padu (8). Kako više nije prioritetan javnozdravstveni problem, svijest o tuberkulozi i među zdravstvenim radnicima i među općom populacijom može se smanjiti te dovesti do kašnjenja u otkrivanju i početku liječenja tuberkuloze (9).

Cilj je ovog rada odrediti dužinu razdoblja između početka simptoma i početka terapije te analizirati čimbenike koji na to utječu. Rezultati istraživanja mogli bi se upotrijebiti kao koristan vodič u planiranju aktivnosti kojima je cilj unaprijediti postojeći sustav nadzora nad tuberkulozom.

\section{METODE}

\section{Ustroj istraživanja}

U ovome presječnom istraživanju sudjelovalo je sedam slučajno odabranih hrvatskih županija (Grad Zagreb, Istarska, Krapinsko-zagorska, Osječkobaranjska, Splitsko-dalmatinska, Zadarska i Zagrebačka županija), čime je obuhvaćeno gotovo $50 \%$ svih slučajeva tuberkuloze u Hrvatskoj tijekom prethodne godine (10) i više od $50 \%$ ukupnog stanovništva Hrvatske. Skupina iskusnih epidemiologa koji sudjeluju u nadzoru nad tuberkulozom na županijskim razinama nakon dva jednodnevna treninga za potrebe izvođenja istraživanja započela je $\mathrm{s}$ anketiranjem tuberkuloznih bolesnika. Intervjui su provedeni u bolnicama ili domovima bolesnika sa strukturiranim upitnikom te je pregledana njihova medicinska dokumentacija odmah nakon što je tuberkuloza dijagnosticirana ili unutar mjesec dana. Upitnik je sadržavao podatke o rizičnom načinu života te različitim demografskim, socioekonomskim i zdravstvenim obilježjima. Izmedicinske dokumentacije zabilježeni su potrebni podaci (primjerice simptomi, dijagnostički proces, laboratorijski i radiološki nalazi i dr.). Podaci o nalazima rendgenskog snimanja pluća zabilježeni su iz nalaza radiologa, a ne rendgenskih slika. Ako se trajanje simptoma razlikovalo između podataka iz medicinske dokumentacije i odgovora ispitanika, zabilježen je datum kraćeg trajanja simptoma.

Istraživanje je odobrilo Etičko povjerenstvo Nastavnog zavoda za javno zdravstvo Splitskodalmatinske županije, a svi ispitanici dali su informirani pristanak.

\section{Kriterij uključenja i isključenja ispitanika}

U istraživanje su uključeni svi bolesnici s plućnom tuberkulozom, s pozitivnim kulturama na Mycobacterium tuberculosis u izabranim županijama, u dobi od 15 i više godina, a oboljeli su između travnja i prosinca 2006. godine.

Bolesnici koji su otkriveni tijekom obrade kontakata drugog slučaja tuberkuloze, koji su otkriveni iz nekih drugih razloga (primjerice prijeoperativna obrada i sl.) i oni koji su već imali tuberkulozu isključeni su iz istraživanja.

\section{Definicije}

Kašnjenjem se smatrao broj dana od početka simptoma do početka liječenja tuberkuloze. Premda 
datum dijagnoze rijetko kada nije bio i dan na koji je započeta terapija, izabrali smo datum početka terapije kao posljednji promatrani dan. U nedostatku standardnih definicija dugo je kašnjenje definirano kao razdoblje koje prelazi medijan kašnjenja u promatranoj populaciji, dok je za ekstremno kašnjenje kao prijelomna točka uzet 75. percentil.

Prema pušačkomu statusu bolesnici su podijeljeni u nepušače (oni koji nisu nikad pušili), bivše pušače (nekoć su pušili, ali više ne puše) i trenutačne pušače. Prema konzumaciji alkohola u posljednjih 12 mjeseci bolesnici su svrstani u ove skupine: nisu konzumirali, prije su konzumirali (oni koji su konzumirali bilo kada tijekom prethodnih 12 mjeseci, ali više ne konzumiraju) i sadašnji konzumenti. Prema indeksu tjelesne mase
$\left(\mathrm{BMI} / \mathrm{kg} \mathrm{m}^{-2}\right)$ bolesnici su bili pothranjeni $(\mathrm{BMI}<18,5)$, normalno uhranjeni $(18,5<\mathrm{BMI}<25)$ i prekomjerno uhranjeni (BMI $\geq 25)$.

\section{Analiza podataka}

$\mathrm{Za}$ istraživanje kašnjenja izračunani su medijan $\mathrm{i}$ 75. percentil ukupnog kašnjenja te svake ispitivane varijable. Hi-kvadrat testom su unutar svake varijable uspoređene frekvencije ispitanika $\mathrm{s}$ kašnjenjem manjim ili jednakim medijanu kašnjenja (ili 75 . percentilu) s kašnjenjem većim od medijana (ili 75 . percentila). Prediktivni čimbenici za kašnjenje analizirani su univarijantnom logističkom regresijom rabeći medijan, odnosno 75. percentil kao prijelomnu točku te su izračunani omjeri izgleda (OR) i 95 \%-tni

Tablica 1 Kašnjenje u otkrivanju i početku liječenja tuberkuloze prema demografskim i socioekonomskim osobitostima

\begin{tabular}{|c|c|c|c|c|}
\hline Osobitost & Broj & $\begin{array}{l}\text { Medijan } \\
\text { / dani }\end{array}$ & 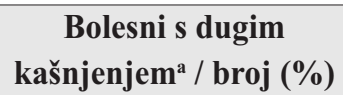 & 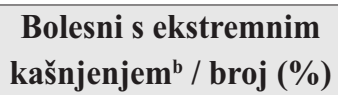 \\
\hline Spol & Ukupno 240 & & & \\
\hline Muški & 134 & 69 & $67(50,0)$ & $36(26,9)$ \\
\hline Ženski & 106 & 67 & $52(49,1)$ & $20(18,9)$ \\
\hline Dobna skupina & Ukupno 240 & & & \\
\hline 15 do 34 & 48 & 69,5 & $24(50,0)$ & $8(16,7)$ \\
\hline 35 do 64 & 131 & 68 & $65(49,6)$ & $34(26,0)$ \\
\hline $65+$ & 61 & 67 & $30(49,2)$ & $14(23,0)$ \\
\hline Bračni status & Ukupno 240 & & & \\
\hline S partnerom & 137 & 71 & $46(44,7)$ & $25(24,3)$ \\
\hline Bez partnera & 103 & 67 & $73(53,3)$ & $31(22,6)$ \\
\hline Država rođenja & Ukupno 240 & & & \\
\hline Hrvatska & 183 & 67 & $30(52,6)$ & $14(24,6)$ \\
\hline U inozemstvu & 57 & 75 & $89(48,6)$ & $42(23,0)$ \\
\hline $\begin{array}{l}\text { Najviši završeni stupanj } \\
\text { obrazovanja }\end{array}$ & Ukupno 240 & & & \\
\hline $\begin{array}{l}\text { Bez završene osnovne škole } \\
\text { i s njom }\end{array}$ & 116 & 90 & $61(52,6)$ & $39(33,6)^{c}$ \\
\hline Srednja škola & 101 & 67 & $44(43,1)$ & $16(15,8)$ \\
\hline Više i visoko obrazovanje & 23 & 64 & $10(43,5)$ & $1(4,3)$ \\
\hline Radni status & Ukupno 240 & & & \\
\hline Zaposlen & 90 & 67 & $43(47,8)$ & $17(18,9)$ \\
\hline Nezaposlen & 42 & 71,5 & $21(50,0)$ & $13(31,0)$ \\
\hline Umirovljenik/kućanica/student & 108 & 70 & $55(50,9)$ & $26(24,1)$ \\
\hline $\begin{array}{l}\text { Ukupan obiteljski mjesečni prihod } \\
\text { po osobi }{ }^{\text {d }}\end{array}$ & Ukupno 210 & & & \\
\hline$\leq$ Minimalna plaća & 108 & 69 & $54(50,0)$ & $27(25,0)^{\mathrm{c}}$ \\
\hline Minimalna do prosječna plaća & 71 & 75 & $40(56,3)$ & $21(29,6)^{\mathrm{c}}$ \\
\hline Iznad prosječne plaće & 31 & 64 & $12(38,7)$ & $2(6,5)$ \\
\hline
\end{tabular}


Tablica 2 Kašnjenje u otkrivanju i početku liječenja tuberkuloze prema osobitostima rizičnoga životnog stila

\begin{tabular}{|c|c|c|c|c|}
\hline Osobitost & Broj & $\begin{array}{l}\text { Medijan } \\
\text { / dani }\end{array}$ & 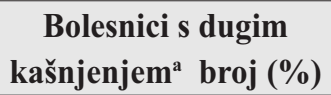 & 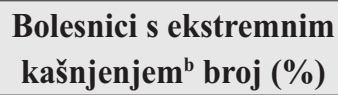 \\
\hline $\begin{array}{l}\text { Kućni kontakt s tuberkuloznim } \\
\text { bolesnikom }\end{array}$ & Ukupno 240 & & & \\
\hline $\mathrm{Da}$ & 47 & 67 & $21(44,7)$ & $8(17,0)$ \\
\hline $\mathrm{Ne}$ & 193 & 70 & $98(50,8)$ & $48(24,9)$ \\
\hline $\begin{array}{l}\text { Kontakt izvan kućanstva s } \\
\text { tuberkuloznim bolesnikom }\end{array}$ & Ukupno 240 & & & \\
\hline $\mathrm{Da}$ & 83 & 90 & $47(56,6)$ & $25(30,1)$ \\
\hline $\mathrm{Ne}$ & 157 & 67 & $72(45,9)$ & $31(19,7)$ \\
\hline Pušačke navike & Ukupno 239 & & & \\
\hline Nepušač & 76 & 67 & $34(44,7)$ & $12(15,8)$ \\
\hline Bivši pušač & 80 & 73 & $43(53,8)$ & $20(25,0)$ \\
\hline Pušač & 83 & 68 & $41(49,4)$ & $24(28,9)^{\mathrm{c}}$ \\
\hline $\begin{array}{l}\text { Konzumacija alkohola u } \\
\text { posljednjih } 12 \text { mjeseci }\end{array}$ & Ukupno 240 & & & \\
\hline $\mathrm{Ne}$ & 103 & 70 & $55(53,4)$ & $25(24,3)$ \\
\hline Prije da, sada ne & 28 & 91 & $15(53,6)$ & $9(32,1)$ \\
\hline Da, sada & 109 & 67 & $49(45,0)$ & $22(20,2)$ \\
\hline Pijanstvo & Ukupno 240 & & & \\
\hline Da, često & 24 & 109,5 & $14(58,3)$ & $8(33,3)$ \\
\hline Da, rijetko & 84 & 67 & $38(45,2)$ & $22(26,2)$ \\
\hline Nikad & 132 & 70 & $67(50,8)$ & $26(19,7)$ \\
\hline Uporaba droga & Ukupno 240 & & & \\
\hline $\mathrm{Da}$ & 13 & 97 & $11(84,6)^{d}$ & $4(30,8)$ \\
\hline $\mathrm{Ne}$ & 227 & 67 & $108(47,6)$ & $52(22,9)$ \\
\hline
\end{tabular}

a duže od medijana ukupnog kašnjenja (68 dana)

${ }^{b}$ duže od 75. percentila ukupnog kašnjenja (120 dana)

${ }^{c} p \leq 0,05$ u univarijantnoj logističkoj regresiji rabeći 75. percentil (120 dana) kao prijelomnu točku

${ }^{d} \leq 0,05$ u univarijantnoj logističkoj regresiji rabeći medijan (68 dana) kao prijelomnu točku

intervali pouzdanosti (CI). Kako bi se dobile varijable nezavisno povezane s dugim i ekstremnim kašnjenjem, napravljena je multivarijantna (višestruka) stupnjevita logistička regresija u koju su uključene sve varijable koje su bile značajne u univarijantnoj logističkoj regresijskoj analizi, zajedno sa spolom i dobnim skupinama kao uobičajenim pristranostima ili „zbunjujućim” varijablama. Pritom se rabila strategija gradnje modela kakvu su predložili Hosmer i Lemeshow (10). Razinom statističke značajnosti smatrala se vrijednost od $\mathrm{P} \leq 0,05$. Podaci su analizirani računalnim programom Statistica 8.0 (StatSoft Inc., Tulsa, SAD).

\section{REZULTATI}

U istraživanju je sudjelovalo 240 tuberkuloznih bolesnika, od kojih su 134 (56 \%) bili muškog spola, a 106 (44 \%) ženskoga. Medijan kašnjenja u otkrivanju i liječenju tuberkuloze iznosio je 68 dana, dok je ekstremno kašnjenje (75. percentil) iznosilo 120 dana (5. i 95. percentil iznosili su 14 i 285 dana).

Ukupno kašnjenje može se podijeliti ovako: $16,7 \%$ ispitanika započelo je liječenje unutar mjesec dana od početka simptoma, 23,8 \% u drugome mjesecu, 23,3\% u trećem mjesecu, 12,9\% u četvrtome mjesecu, dok je u 23,3 \% ispitanika liječenje započelo više od četiri mjeseca nakon početka simptoma.

Deskriptivne informacije o statistički značajnim i ostalim epidemiološki relevantnim varijablama, kao što su demografska i socioekonomska obilježja (tablica 1), rizični životni stil (tablica 2) te karakteristike zdravstvenog stanja (tablica 3 ) prikazane su u navedenim tablicama.

Uporaba droga bila je statistički značajno povezana s dugim kašnjenjem ( $\mathrm{p}=0,021, \mathrm{OR}=6,06$; $95 \%$-tni $\mathrm{CI}=1,31$ do 27,96), dok se kod ekstremnog 
Tablica 3 Kašnjenje u otkrivanju i početku liječenja tuberkuloze prema osobitostima zdravstvenog stanja

\begin{tabular}{|c|c|c|c|c|}
\hline Osobitost & Broj & $\begin{array}{c}\text { Medijan / } \\
\text { dani }\end{array}$ & $\begin{array}{c}\text { Bolesnici s dugim } \\
\text { kašnjenjem } \\
\text { broj }(\%)\end{array}$ & 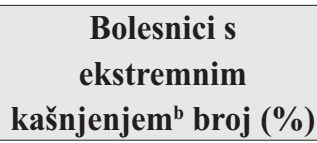 \\
\hline Komorbiditet & Ukupno 240 & & & \\
\hline $\mathrm{Da}$ & 101 & 75 & $55(54,5)$ & $30(29,7)^{\mathrm{c}}$ \\
\hline $\mathrm{Ne}$ & 139 & 67 & $64(46,0)$ & $26(18,7)$ \\
\hline $\begin{array}{l}\text { Kaverne na rendgenskoj snimci } \\
\text { pluća }\end{array}$ & Ukupno 240 & & & \\
\hline $\mathrm{Da}$ & 64 & 69,5 & $32(50,0)$ & $17(26,6)$ \\
\hline $\mathrm{Ne}$ & 176 & 67 & $87(49,4)$ & $39(22,2)$ \\
\hline Uzorak & Ukupno 240 & & & \\
\hline Iskašljaj & 197 & 68 & $97(49,2)$ & $46(23,4)$ \\
\hline Drugo & 43 & 75 & $22(51,2)$ & $10(23,3)$ \\
\hline
\end{tabular}

Mikroskopski pozitivan razmaz iskašljaja

Ukupno 240

\begin{tabular}{|c|c|c|c|c|}
\hline $\mathrm{Da}$ & 165 & 67 & $77(46,7)$ & $37(22,4)$ \\
\hline $\mathrm{Ne}$ & 75 & 75 & $42(56,0)$ & $19(25,3)$ \\
\hline Kašalj & Ukupno 240 & & & \\
\hline $\mathrm{Da}$ & 176 & 70 & $92(52,3)$ & $42(23,9)$ \\
\hline $\mathrm{Ne}$ & 64 & 64.5 & $27(42,2)$ & $14(21,9)$ \\
\hline Kašalj s iskašljavanjem krvi & Ukupno 240 & & & \\
\hline $\mathrm{Da}$ & 42 & 67 & $20(47,6)$ & $11(26,2)$ \\
\hline $\mathrm{Ne}$ & 198 & 69 & $99(50,0)$ & $45(22,7)$ \\
\hline Povišena temperatura & Ukupno 240 & & & \\
\hline $\mathrm{Da}$ & 115 & 67 & $51(44,3)$ & $23(20,0)$ \\
\hline $\mathrm{Ne}$ & 125 & 75 & $68(54,4)$ & $33(26,4)$ \\
\hline Gubitak tjelesne težine & Ukupno 240 & & & \\
\hline $\mathrm{Da}$ & 137 & 75 & $74(54,0)$ & $36(26,3)$ \\
\hline $\mathrm{Ne}$ & 103 & 67 & $45(43,7)$ & $20(19,4)$ \\
\hline Noćno znojenje & Ukupno 240 & & & \\
\hline $\mathrm{Da}$ & 111 & 67 & $53(47,7)$ & $27(24,3)$ \\
\hline $\mathrm{Ne}$ & 129 & 70 & $66(51,2)$ & $29(22,5)$ \\
\hline Nestašica zraka & Ukupno 240 & & & \\
\hline $\mathrm{Da}$ & 73 & 75 & $39(53,4)$ & $21(28,8)$ \\
\hline $\mathrm{Ne}$ & 167 & 67 & $80(47,9)$ & $35(21,0)$ \\
\hline Umor & Ukupno 240 & & & \\
\hline $\mathrm{Da}$ & 155 & 70 & $80(51,6)$ & $40(25,8)$ \\
\hline $\mathrm{Ne}$ & 85 & 67 & $39(45,9)$ & $16(18,8)$ \\
\hline
\end{tabular}

Indeks tjelesne mase na dan intervjua

Ukupno 236

\begin{tabular}{lcccc}
\hline Pothranjenost & 31 & 67 & $15(48,4)$ & $11(35,5)$ \\
\hline Normalna uhranjenost & 155 & 70 & $79(51,0)$ & $35(22,6)$ \\
\hline Prekomjerna uhranjenost & 50 & 67 & $23(46,0)$ & $10(20,0)$ \\
\hline
\end{tabular}

a duže od medijana ukupnog kašnjenja (68 dana)

${ }^{b}$ duže od 75. percentila ukupnog kašnjenja (120 dana)

${ }^{c} p \leq 0,05$ u univarijantnoj logističkoj regresiji rabeći 75 . percentil (120 dana) kao prijelomnu točku

kašnjenja značajnost uočila kod najnižeg stupnja obrazovanja $(\mathrm{p}=0,021 ; \mathrm{OR}=11,14 ; 95 \%$-tni $\mathrm{CI}=1,45$ do 85,75), minimalnog ( $\mathrm{p}=0,039 ; \mathrm{OR}=4,83 ; 95 \%$-tni $\mathrm{CI}=1,08$ do 21,61) te minimalnog do prosječnog obiteljskog prihoda $(\mathrm{p}=0,020 ; \mathrm{OR}=6,09 ; 95 \%$-tni $\mathrm{CI}=1,33$ do 27,87), sadašnjeg pušenja $(\mathrm{p}=0,050$; $\mathrm{OR}=2,17 ; 95 \%$-tni $\mathrm{CI}=1,00$ do 4,72$)$ i komorbiditeta $(\mathrm{p}=0,048 ; \mathrm{OR}=1,84 ; 95 \%$-tni $\mathrm{CI}=1,00$ do 3,36). 
Tablica 4 Logistička regresijska analiza $a^{a}$ ekstremnog kašnjenja ${ }^{b}$ otkrivanju i početku liječenja tuberkuloze

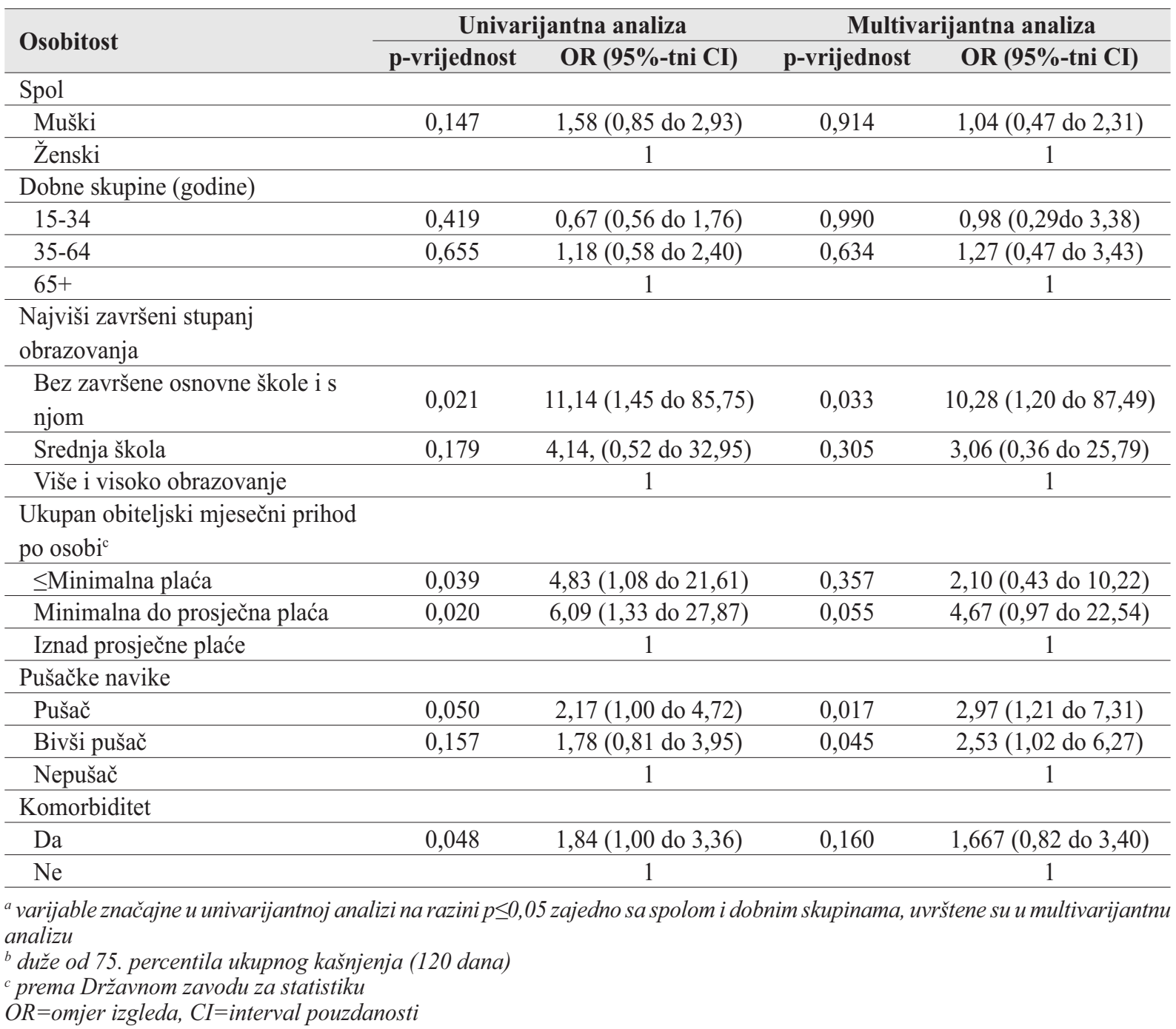

U multivarijantnome modelu dugo je kašnjenje ostalo povezano s uporabom droga $(\mathrm{p}=0,021$; $\mathrm{OR}=6,06 ; 95 \%$-tni $\mathrm{CI}=1,31$ do 27,96), dok su se najniži stupanj obrazovanja $(\mathrm{p}=0,033$; OR $=10,25$; $95 \%$-tni $\mathrm{CI}=1,20$ do 87,49), sadašnje ( $\mathrm{p}=0,017$; $\mathrm{OR}=2,97 ; 95 \%$-tni $\mathrm{CI}=1,21$ do 7,31$)$ i bivše pušačke navike ( $\mathrm{p}=0,045 ; \mathrm{OR}=2,53 ; 95 \%$-tni $\mathrm{CI}=1,02$ do 6,27 ) pokazali značajno povezanima s ekstremnim kašnjenjem (tablica 4).

\section{RASPRAVA}

U ovom istraživanju pokazalo se da je medijan razdoblja od nastupa simptoma do početka antituberkulozne terapije 68 dana, dok je ekstremno kašnjenje (75. percentil) 120 dana. Ti su rezultati usporedivi s rezultatima iz drugih industrijaliziranih zemalja (12-15) i mnogo manji od onih iz zemalja visoke incidencije (16-18).

Za razliku od drugih istraživanja $(13,18-21)$, nije uočeno da postoji razlika po spolovima vezana uz kašnjenje. Jednako pravo i pristup zdravstvenim uslugama jedno je od prava zajamčenih Ustavom, što se reflektira i u ovim rezultatima.

Podatak da bolesnici koji imaju više od osam godina formalnog školovanja manje kasne od onih koji imaju samo završenu osnovnu školu ili su bez nje ne čudi jer je pronađen i u drugim radovima (9). U jednom istraživanju iz Hrvatske (22) pokazalo se da je bolje znanje o tuberkulozi povezano s višim stupnjem obrazovanja, nakon što su se isključili drugi demografski i socioekonomski čimbenici. Zaključeno je da su najmlađe dobne skupine ispitanika i oni koji su najlošije obrazovani ciljne skupine za intervencijske strategije (22). 
Zanimljivo je da se socioekonomski čimbenici nisu pokazali povezanima s dugim ili ekstremnim kašnjenjem, za razliku od drugih radova (23). Vjerujemo da se to može objasniti činjenicom da su dijagnostika i liječenje tuberkuloze u Hrvatskoj besplatni. To vrijedi za sve osobe, bez obzira na to jesu li zdravstveno osigurane ili nisu, premda je više od $98 \%$ hrvatske populacije u vrijeme provođenja istraživanja imalo zdravstveno osiguranje (24).

Među čimbenicima vezanim uz rizični životni stil pokazalo se da bolesnici koji su često bili alkoholizirani te oni koji uzimaju drogu imaju najduži medijan (5, $9,23,25)$. Ti podaci ne čude s obzirom na to da takve osobe obično ne vode brigu o vlastitom zdravlju. Više od polovice bolesnika imalo je neku od popratnih bolesti, što se pokazalo statistički značajno povezanim s ekstremnim kašnjenjem, u skladu s rezultatima drugih istraživanja (12).

Plućna tuberkuloza s pozitivnim razmazima iskašljaja dijagnosticirana je u $69 \%$ ispitanika. Postojanje negativnih nalaza razmaza bilo je povezano s dužim medijanom kašnjenja, što upućuje na moguću slabu točku u dijagnostici tuberkuloze i naglašava potrebu za novim testovima za brzu dijagnozu, čemu u prilog govore i drugi radovi $(14,21,26)$. S druge strane, ta razlika nije bila statistički značajna. To bi se moglo objasniti činjenicom da se, prema Naputku za suzbijanje i sprečavanje tuberkuloze (27), liječenje može započeti već na osnovi kliničke sumnje prije nalaza kulture. Propisano je i da laboratoriji trebaju na vrijeme javiti nalaze mikobakterioloških pretraga, $i$ to mikroskopske nalaze unutar 24 sata, kultivacijske nalaze unutar 14 dana te identifikaciju M. tuberculosis unutar 21 dana (27).

Kao i u drugim radovima kašalj, gubitak tjelesne težine, povišena temperatura i umor bili su najčešće prijavljeni simptomi $(6,9,12,23,25)$. Međutim pokazalo se da postojanje bilo kojeg simptoma nije povezano s kraćim kašnjenjem, što upućuje na činjenicu da ti simptomi nisu pobudili sumnju (oprez) ni samih ispitanika, a ni liječnika. Isto tako je moguće da ovi simptomi nastanu i kao rezultat uznapredovale bolesti koja nije liječena, odnosno da su posljedica kašnjenja.

Kašalj može biti povezan s pušenjem, s obzirom na to da su više od dvije trećine ispitanika bili pušači, bilo sadašnji ili bivši, koji mogu imati „pušački“" kašalj. Međutim gubitak težine, povišena temperatura i umor mogu biti pokazatelji niza potencijalno teških bolesti, zanemarivanje kojih može dovesti do uznapredovale bolesti i veće smrtnosti.
U Hrvatskoj je uobičajeno da primarnu zdravstvenu zaštitu osoba iznad 7 godina pružaju liječnici opće/ obiteljske medicine. Mreža takvih liječnika, kao i razvijena mreža od 14 mikobakterioloških laboratorija smatra se dovoljnom za pružanje odgovarajuće dijagnostičke obrade i skrbi o tuberkuloznim bolesnicima $(8,28,29)$. Ovakva organizacija sigurno smanjuje ograničenja u pristupu zdravstvenim uslugama poput udaljenosti i dugog vremena putovanja do zdravstvene ustanove, kako je opisano u drugim radovima $(23,30)$.

Stoga unatoč dostupnosti zdravstvene zaštite zabrinjava činjenica da više od polovice bolesnika ne započne liječenje više od dva mjeseca nakon pojave simptoma, dok je značajan dio bolesnika $(23,1 \%)$ puna četiri mjeseca nakon pojave simptoma još uvijek izvor zaraze u populaciji.

Rezultate ovog istraživanja treba tumačiti u svjetlu nekih ograničenja. Prvo, činjenica da se bolesnici moraju prisjetiti trajanja simptoma prije traženja liječničke pomoći može biti uzrokom pogreške sjećanja. Određivanje točnog datuma pojave simptoma ograničenje je svih sličnih istraživanja $(21,23,25)$. To se nastojalo izbjeći na više načina. Istraživanje je posebno osmišljeno za ovu svrhu. Bolesnici su uzastopno uključivani u istraživanje te su potrebni podaci dobiveni od njih intervjuom, a ne samo pregledom medicinske dokumentacije. Svi su intervjui napravljeni netom nakon što je dijagnoza postavljena uz iznimne napore da se definira točan datum početka simptoma. Smatramo da je ovaj pristup pridonio točnosti podataka.

Jakost ovog istraživanja jesu strogi kriteriji uključivanja i isključivanja bolesnika. Jedino su zarazni slučajevi bolesti, potvrđeni kultiviranjem, bili dijelom istraživanja, dok su se isključili bolesnici kod kojih je bolest slučajno pronađena budući da je to moglo dovesti do podcjenjivanja kašnjenja. Županije u kojima se provelo istraživanje odabrane su slučajno; stoga su populacije s različitim stopama incidencije, kao i liječnici s različitim iskustvom i sumnjom na tuberkulozu bili sudionici istraživanja.

\section{ZAKLJUČAK}

Kako bi se smanjio razorni učinak tuberkuloze na osobnoj i obiteljskoj razini te razini zajednice, tuberkuloza bi se trebala otkriti što je ranije moguće, i ranim javljanjem bolesnika kad primijete simptome i ranim otkrivanjem od strane zdravstvenog sustava. 
Prikazano kašnjenje u otkrivanju i liječenju tuberkuloze moglo bi se smanjiti zdravstvenim prosvjećivanjem opće populacije ne samo o tuberkulozi nego i općenito o zdravlju i stavovima o prevenciji i ranom liječenju. Javnost treba naučiti kako prepoznati simptome bolesti i kako razviti model ponašanja u kojem se rano traži liječnička pomoć kontinuiranom edukacijom o zdravlju.

$\mathrm{U}$ isto vrijeme edukacija o tuberkulozi među zdravstvenim radnicima mora se intenzivirati. Procijenjeno je da svaki liječnik opće/obiteljske medicine ima u prosjeku jednog tuberkuloznog bolesnika svake dvije godine (29). U takvim okolnostima razumno je pretpostaviti da mnogi važni postupci vezani uz nadzor nad tuberkulozom možda nisu ispravno provedeni zbog nedostatnog iskustva i znanja o tuberkulozi.

Zbog nespecifične prirode mnogih simptoma i znakova tuberkuloze, zajedno sa sporim, ali kontinuiranim smanjivanjem stopa incidencije tuberkuloze, nerealno je očekivati da svi slučajevi tuberkuloze budu brzo dijagnosticirani bez dobrog znanja o tuberkulozi i prisutne sumnje na nju u diferencijalnoj dijagnozi $(19,26)$.

Kašalj, kao najčešći simptom tuberkuloze, ima različito značenje ovisno o prevalenciji tuberkuloze u promatranoj populaciji. Za razliku od zemalja visoke incidencije, u zemljama niske ili srednje incidencije kašalj je češće uzrokovan drugim respiratornim bolestima (19). Bez obzira na to, pasivno otkrivanje slučajeva treba biti brzo, dok aktivno pronalaženje slučajeva treba biti intenzivnije. Trenutačno se aktivnim traženjem među kontaktima tuberkuloznih bolesnika i među rizičnim skupinama otkrije $5 \%$, odnosno $2 \%$ od ukupno prijavljenih tuberkuloznih bolesnika (27). Novi naputak za suzbijanje i sprječavanje tuberkuloze može biti koristan jer pruža dijagnostički postupnik te informacije o brzoj mikrobiološkoj dijagnostici tuberkuloze (27).

Javnozdravstvene intervencije su potrebne kako bismo se brže i uspješnije usmjerili eliminaciji tuberkuloze, što uključuje i intenzivne napore na različitim razinama od mijenjanja ponašanja usmjerenog traženju zdravstvene usluge, unaprjeđivanja svijesti o tuberkulozi i povećavanja dijagnostičke sumnje zdravstvenih radnika, kao i usavršavanja njihova znanja o tuberkulozi.

\section{Zahvale}

Zahvalni smo svim epidemiolozima koji su sudjelovali u prikupljanju podataka jer su znatno pridonijeli uspješnomu vođenju ovog istraživanja.

\section{LITERATURA}

1. World Health Organization (WHO). Global Tuberculosis Control 2011. Geneva: WHO; 2011.

2. World Health Organization (WHO). The Stop TB Strategy. Geneva: WHO; 2006.

3. Styblo K. Epidemiology of Tuberculosis. $2^{\text {nd }}$ ed. The Hague: The Royal Netherlands Tuberculosis Association; 1991.

4. Rieder HL. Epidemiologic Basis of Tuberculosis Control. Paris: IUATLD; 1999.

5. dos Santos MA, Albuquerque MF, Ximenes RA, LucenaSilva NL, Braga C, Campelo AR, Dantas OMS, Montarroyos UR, Souza WV, Kawasaki AM, Rodrigues LC. Risk factors for treatment delay in pulmonary tuberculosis in Recife, Brazil. BMC Public Health 2005;5:25.

6. Storla DG, Yimer S, Bjune GA. A systematic review of delay in the diagnosis and treatment of tuberculosis. BMC Public Health 2008;8:15.

7. Sreeramareddy CT, Panduru KV, Menten J, Van den Ende J. Time delays in diagnosis of pulmonary tuberculosis: a systematic review of literature. BMC Infect Dis 2009;9:91.

8. Jurčev Savičević A, Katalinić-Janković V, Gjenero-Margan I, Šimunović A, Vidić Đ, Gunjača J, Obrovac M. Epidemiological patterns of tuberculosis in Croatia in the period 1996-2005. Coll Antropol 2011;35:523-8.

9. Golub JE, Bur S, Cronin WA, Gange S, Baruch N, Comstock GW, Chaisson RE. Patient and health care system delays in pulmonary tuberculosis diagnosis in a low-incidence state. Int J Tuberc Lung Dis 2005;9:992-8.

10. Hrvatski zavod za javno zdravstvo. Hrvatski zdravstvenostatistički ljetopis 2006. Zagreb: Hrvatski zavod za javno zdravstvo; 2007.

11. Hosmer DW, Lemeshow S. Applied logistic regression. $2^{\text {nd }}$ ed. New York (NY): John Wiley \& Sons; 2000.

12. Farah MG, Rygh JH, Steen TW, Selmer R, Heldal E, Bjune G. Patient and health care system delays in the start of tuberculosis treatment in Norway. BMC Infect Dis 2006;6:33.

13. Rodger A, Jaffar S, Paynter S, Hayward A, Carless J, Maguire H. Delay in the diagnosis of pulmonary tuberculosis, London, 1998-2000: analysis of surveillance data. BMJ 2003;326:909-10.

14. Sherman LF, Fujiwara PI, Cook SV, Bazerman LB, Frieden TR. Patient and health care system delays in the diagnosis and treatment of tuberculosis. Int J Tuberc Lung Dis 1999;3:1088-95.

15. Gagliotti C, Resi D, Moro ML. Delay in the treatment of pulmonary $\mathrm{TB}$ in a changing demographic scenario. Int $\mathrm{J}$ Tuberc Lung Dis 2006;10:305-9.

16. Wandwalo ER, Mørkve O. Delay in tuberculosis case-finding and treatment in Mwanza, Tanzania. Int J Tuberc Lung Dis 2000;4:133-8.

17. Ngadaya ES, Mfinanga GS, Wandwalo ER, Morkve O. Delay in tuberculosis case detection in Pwani region, Tanzania. A cross sectional study. BMC Health Serv Res 2009;9:196.

18. Ouédraogo M, Kouanda S, Boncoungou K, Dembélé M, Zoubga ZA, Ouédraogo SM, Coulibaly G. Treatment seeking behaviour of smear-positive tuberculosis patients diagnosed in Burkina Faso. Int J Tuberc Lung Dis 2006;10:184-7. 
19. Ward J, Siskind V, Konstantinos A. Patient and health care system delays in Queensland tuberculosis patients, 19851998. Int J Tuberc Lung Dis 2001;5:1021-7.

20. Lawn SD, Afful B, Acheampong JW. Pulmonary tuberculosis: diagnostic delay in Ghanaian adults. Int J Tuberc Lung Dis 1998;2:635-40.

21. Chiang CY, Chang CT, Chang RE, Li CT, Huang RM. Patient and health system delays in the diagnosis and treatment of tuberculosis in Southern Taiwan. Int J Tuberc Lung Dis 2005;9:1006-12.

22. Jurcev Savicevic A, Popovic Grle S, Milovac S, Vukasovic M, Ivcevic I, Viali V, Zivkovic K. Tuberculosis knowledge among patients in out-patient settings in Split, Croatia. Int J Tuberc Lung Dis 2008;12:780-5

23. Rajeswari R, Chandrasekaran V, Suhadev M, Sivasubramaniam S, Sudha G, Renu G. Factors associated with patient and health system delays in the diagnosis of tuberculosis in South India. Int J Tuberc Lung Dis 2002;6:789-95.

24. Hrvatski zavod za zdravstveno osiguranje. Izvješće o financijskom poslovanju Hrvatskog zavoda za zdravstveno osiguranje u razdoblju od I. do XII. 2006. godine. [pristup 2. listopada 2011.]. Dostupno na http://www.hzzo-net. hr/05_03_01.php
25. van der Werf MJ, Chechulin Y, Yegorova OB, Marcinuk T, Stopolyanskiy A, Voloschuk V, Zlobinec M, Vassall A, Veen J, Hasker E, Turchenko LV. Health care seeking behaviour for tuberculosis symptoms in Kiev City, Ukraine. Int J Tuberc Lung Dis 2006;10:390-5.

26. Liam CK, Tang BG. Delay in the diagnosis and treatment of pulmonary tuberculosis in patients attending a university teaching hospital. Int J Tuberc Lung Dis 1997;1:326-32.

27. Ministarstvo zdravstva i socijalne skrbi Republike Hrvatske i Hrvatski zavod za javno zdravstvo. Naputak za suzbijanje i sprečavanje tuberkuloze. Zagreb: Ministarstvo zdravstva i socijalne skrbi Republike Hrvatske i Hrvatski zavod za javno zdravstvo; 2010.

28. Jurčev Savičević A. Gaps in tuberculosis knowledge among primary health care physicians in Croatia: epidemiological study. Coll Antropol 2009;33:481-6.

29. Hrvatski zavod za javno zdravstvo. Hrvatski zdravstvenostatistički ljetopis 2009. Zagreb: Hrvatski zavod za javno zdravstvo; 2010.

30. Gele AA, Bjune G, Abebe F. Pastoralism and delay in diagnosis of TB in Ethiopia. BMC Public Health 2009;9:5. 


\section{Summary \\ DELAYS IN DIAGNOSING AND TREATING TUBERCULOSIS IN CROATIA}

The aim of this study was to determine factors causing delay in tuberculosis diagnosis and treatment in Croatia. It included 240 adults with pulmonary tuberculosis, who were interviewed for demographics, socioeconomic, lifestyle, and personal health data. Total delay was defined as a number of days from the onset of symptoms to the initiation of therapy. The median and the $75^{\text {th }}$ percentile of the total delay were 68 and 120 days, respectively: $16.7 \%$ of the patients initiated treatment within the first month , $23.8 \%$ within the second month, $23.3 \%$ within the third month, $12.9 \%$ within the fourth month, and $23.3 \%$ more than four months after the symptoms appeared. Long delay (exceeding median delay) was strongly associated with drug abuse $(\mathrm{p}=0.021)$. Extreme delay $\left(75^{\text {th }}\right.$ percentile of delay) was significantly associated with the lowest level of education $(p=0.021)$, below minimal income $(p=0.039)$, minimal to average income $(\mathrm{p}=0.020)$, current smoking $(\mathrm{p}=0.050)$, and co-morbidity $(\mathrm{p}=0.048)$. In the multivariate model, long delay remained associated with drug abuse, while extreme delay was associated with the lowest level of education $(\mathrm{p}=0.033)$ and current $(\mathrm{p}=0.017)$ and ex-smoking $(\mathrm{p}=0.045)$.

In a setting with decreasing TB incidence, the reported delay can be reduced by increasing health education, not only about tuberculosis per se, but about health in general and attitudes towards prevention and early care. It is also important to increase tuberculosis knowledge among healthcare workers as well as their diagnostic skills.

KEY WORDS: alcohol use, co-morbidity, drug abuse education, health care, prevention, smoking

\section{CORRESPONDING AUTHOR:}

Anamarija Jurčev-Savičević

Vukovarska 46, 21000 Split, Croatia

E-mail:anamarijajurcev@yahoo.com 